\title{
Medievalista
}

Online

26 | 2019

Número 26

\section{Os Estudos Medievais em Portugal: Dever de Qualidade e Direito de Cidadania}

\section{A Redacção}

\section{(2) OpenEdition}

1 Journals

\section{Edição electrónica}

URL: http://journals.openedition.org/medievalista/2356

DOI: 10.4000/medievalista.2356

ISSN: 1646-740X

\section{Editora}

Instituto de Estudos Medievais - FCSH-UNL

Edição impressa

Data de publição: 1 junho 2019

\section{Refêrencia eletrónica}

A Redacção, «Os Estudos Medievais em Portugal: Dever de Qualidade e Direito de Cidadania », Medievalista [Online], 26 | 2019, posto online no dia 27 julho 2019, consultado o 23 setembro 2020. URL : http://journals.openedition.org/medievalista/2356; DOI : https://doi.org/10.4000/medievalista. 2356

\section{(c) (1) (8)}

Mediavalista está licenciado com uma Licença Creative Commons - Atribuição-NãoComercial 4.0 Internacional. 
Título / Title: Os Estudos Medievais em Portugal: Dever de Qualidade e Direito de Cidadania Autor(es) / Author(s): A Redacção

Fonte: Medievalista [Em linha]. Direc. Bernardo Vasconcelos e Sousa. Lisboa: IEM. Disponível em:

http://www2.fcsh.unl.pt/iem/medievalista/MEDIEVALISTA26/editorial2601.html ISSN: 1646-740X 


\title{
Os Estudos Medievais em Portugal: Dever de Qualidade e Direito de Cidadania
}

\author{
A Redacção
}

O Instituto de Estudos Medievais realizou de 13 a 15 de Dezembro de 2017 o colóquio "Medieval Europe in Motion. The Middle Ages: a Global Context". Com ele os organizadores pretenderam juntar académicos em torno de uma das linhas do projecto estratégico do IEM: "People and Knowledge in Motion: Medieval Portugal in TransEuropean Networks", de forma a discutir e reavaliar a investigação ligada à mobilidade, circulação de modelos e fenómenos globais na Idade Média.

Este quarto colóquio subordinado à referida temática geral teve uma secção que se centrou nas esculturas românicas de madeira policromada na Europa, abordando o estado da questão e os fundamentos para investigações futuras. Os textos que fazem parte deste número da revista reflectem a preocupação dos investigadores com o estudo destas esculturas, de forma a chamar a atenção para a importância da policromia em obras que nos aparecem hoje como uma pálida imagem da sua realidade original. Um trabalho interdisciplinar de historiadores, historiadores da arte, conservadores e instituições que têm estas peças à sua guarda mostra a importância do estudo material para uma abordagem à escultura medieva e permite imprimir rigor às propostas dos investigadores que vão no sentido de uma pesquisa interdisciplinar que divulgue os seus saberes. A constituição de um corpus, de bases de dados digitais e de análises laboratoriais permite não só a identificação de materiais, da degradação de cores, de repintes, mas também detectar ou pôr em causa origens, cronologias e modelos anteriormente estabelecidos. Além disso, todos os autores são unânimes em referir a necessidade de procurar reconstituir os contextos originais para que foram criadas as esculturas, pois só desse 
modo se poderá compreender o percurso das obras e a importância das trocas culturais que lhes estão associadas.

A Medievalista vem assim dar visibilidade a uma temática ainda pouco explorada, mas cujos resultados apresentados por especialistas de reconhecido mérito dão um importante contributo para o conhecimento global das obras, da circulação de modelos e de artistas, mas que também reúnem material para a sua preservação e restauro. Como muito bem refere Lucretia Kargère no "Destaque" deste número da nossa revista, "os exames técnicos de esculturas de madeira policromada facilitam uma melhor compreensão da sua aparência original como imagens devocionais, onde a policromia cumpriu um papel crítico, seja pelo uso simbólico de justaposições de cores ou pela criação de superfícies deslumbrantes para inspirar o culto".

O dossier temático foi organizado por Lucretia Kargère, especialista em restauro do Cloisters do Metropolitan Museum of Art, de Nova Iorque, de acordo com a proposta apresentada por Alicia Miguélez Cavero à Redacção da Medievalista, que de imediato a aceitou, pelo que aqui deixamos um público agradecimento a ambas. A originalidade e mesmo o carácter pioneiro de vários dos estudos que integram o dossier, a colaboração de grandes especialistas estrangeiros em escultura românica de madeira policromada e a amável anuência para a publicação destes seus textos constituem um imenso orgulho para a Medievalista, apostada como está em promover a difusão do medievalismo nas suas múltiplas vertentes, como expressão de uma efectiva internacionalização que não se confunde com adesões provincianas a qualquer império linguístico.

Além dos referidos trabalhos incluídos na secção dos "Artigos" e devidamente apresentados no "Destaque", contamos com as habituais secções. Assim, publicam-se "Recensões" da autoria de Rui Rocha sobre um livro de Antoine Desemberg que estuda o imaginário social dos universitários medievais; de Victor Muñoz Gómez sobre a obra de Diana Pelaz Flores dedicada aos rituais líquidos no cerimonial da corte castelhana no final da Idade Média; e uma terceira recensão de Leandro Vilar Oliveira sobre a recente edição brasileira de um dicionário de história e cultura viking organizado por Johnni Langer. Na "Apresentação de Teses" contamos com os contributos de Javier Castiñeiras López sobre espaços e imagens na Galiza entre o final do século XI e o início do seguinte, de Joana Lencart sobre Pedro Álvares Seco e a memória da Ordem de Cristo, e de José 
Manuel Simões sobre a visão dos letrados na cronística tardomedieval portuguesa. Finalmente, na "Varia", Paula Pinto Costa informa acerca do Encontro sobre Estudos de História Militar realizado no Porto e Mário Farelo faz o balanço da sexta edição do workshop "Investigar na Idade Média".

Fiel ao seu propósito de garantir diversidade e exigência nos trabalhos publicados, a Medievalista não se tem furtado a tudo fazer, na medida das suas capacidades, para cumprir um "dever de qualidade" que tem sido constante para alargar a sua difusão e reconhecimento entre os estudiosos da Idade Média - da sua história, da sua arte, da sua literatura, da sua arqueologia, enfim, de todas as suas manifestações. $\mathrm{O}$ crescente número de colaborações que vamos recebendo quer de investigadores nacionais quer de estrangeiros, a vontade de publicar na nossa revista por parte de autores que são grandes autoridades internacionais nas respectivas áreas de especialidade, as apreciações positivas de que vamos tendo notícia são para nós como que um atestado do cumprimento desse nosso "dever de qualidade".

Quando se aproxima a fase de divulgação, pela Fundação para a Ciência e a Tecnologia, dos resultados da avaliação dos Centros de Investigação nacionais - com o consequente financiamento - consideramos não ser abusivo reclamar o integral "Direito de Cidadania" para os estudos medievais e para a única Unidade de Investigação que no nosso país se dedica em exclusivo a esta área de investigação, o Instituto de Estudos Medievais. Esse direito que reivindicamos para podermos prosseguir no cumprimento dos nossos deveres face a crescentes exigências em custos humanos e financeiros deverá passar, terá mesmo de passar, por um financiamento que permita uma maior profissionalização da nossa revista, a fim de garantir a sua adequação formal às apertadas normas das plataformas de indexação de publicações periódicas de carácter científico. Esse é um dos grandes desafios com que a Medievalista se confronta.

Por isso queremos continuar a assumir o dever de qualidade. Mas também com o que julgamos ser o nosso pleno "direito de cidadania" no seio da comunidade historiográfica e científica de Portugal.

PS: Com este número termina a colaboração gráfica que Ricardo Naito prestou à Medievalista ao longo dos últimos anos. Sem ele, que não sendo medievalista se deixou 
"contaminar" pela nossa "peste", a revista não seria o que é hoje. Com rigor e bom gosto gráfico, com compreensão para os apertos da Redacção e do Secretariado, nunca nos deixou ficar mal. E a Medievalista foi sempre editada no dia exacto para o lançamento de cada número. Além do reconhecimento e da gratidão, só lhe podemos desejar o maior sucesso nos novos projectos profissionais a que se irá dedicar.

\section{COMO CITAR ESTE ARTIGO}

\section{Referência electrónica:}

Redacção - "Os Estudos Medievais em Portugal: Dever de Qualidade e Direito de Cidadania”. Medievalista 26 (Julho-Dezembro 2019). [Em linha] [Consultado dd.mm.aaaa]. Disponível em http://www2.fcsh.unl.pt/iem/medievalista/MEDIEVALISTA26/editorial2601.html ISSN 1646-740X.

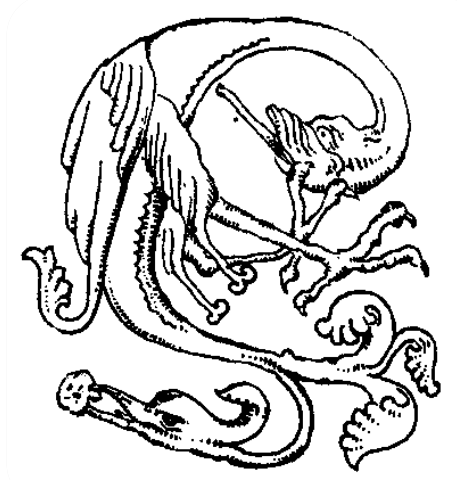

